\title{
CLINICAL FEATURES AND SEVERITY OF GASTRIC EMPTYING DELAY IN BRAZILIAN PATIENTS WITH GASTROPARESIS
}

\author{
Cláudio Marins Rocha BORGES, Marie SECAF and Luiz Ernesto de Almeida TRONCON
}

\begin{abstract}
Context - Gastroparesis is defined by delayed gastric emptying without mechanical obstruction of the gastroduodenal junction, which has been increasingly investigated. Nevertheless, knowledge on the relationships between etiology, symptoms and degree of delayed gastric emptying is limited. Objectives - The demographic, clinical and etiological features of Brazilian patients with gastroparesis were studied and the relationships between these findings and the severity of gastric emptying were determined. Method - This is a retrospective study of medical records of 41 patients with symptoms suggestive of gastroparesis admitted between 1998 and 2011, who had evidence of abnormally delayed gastric emptying on abdominal scintigraphy. Cases with idiopathic gastroparesis were compared with those of patients with neurologic disorders or diabetes mellitus, in whom autonomic neuropathy is likely to occur. Results - The majority of the patients were women (75.6\%) with a median age of 41 years and a long-term condition (median: 15 years). Twelve patients (29.3\%) had a body mass index of less than $20 \mathrm{~kg} / \mathrm{m}^{2}$. The most common presenting symptoms were dyspepsia (53.6\%), nausea and vomiting (46.3\%), weight loss (41.4\%) and abdominal pain (24.3\%). Regarding etiology, 16 patients had digestive disorders including idiopathic gastroparesis $(n=12), 12$ had postoperative conditions, 11 had diseases of the nervous system, five had diabetes mellitus and in three cases gastroparesis was associated to a variety of conditions. In the majority of patients $(65.8 \%)$ gastric emptying was severely delayed. There was no association between etiology of gastroparesis, type of presenting symptoms and the degree of delay in gastric emptying. Gastroparesis patients with proven (neurological conditions) or presumed (diabetes) nervous system involvements were significantly younger $(P=0.001)$, had more recent symptom onset $(P=0: 03)$ and a trend towards more severe gastric empty $(P=0: 06)$. There were no significant differences between this subgroup of patients and that comprising cases of idiopathic gastroparesis regarding any of the variables studied. Conclusions - The demographic, clinical and etiological characteristics of Brazilian patients with gastroparesis are quite varied, but there is a predominance of women with long-standing symptoms and marked delay in gastric emptying. The type of presenting symptoms and the degree of delay in gastric emptying do not predict the etiology of gastroparesis. However, severely delayed gastric emptying in younger patients with recent symptom onset should raise the suspicion of impaired neural control of gastro-duodenal motility.
\end{abstract}

HEADINGS - Gastroparesis. Digestive signs and symptoms. Neuropathies. Diabetes mellitus.

\section{INTRODUCTION}

Gastroparesis is a clinical condition defined by abnormally delayed gastric emptying in the absence of mechanical obstruction of the gastroduodenal junction $^{(4)}$. Clinical manifestations of gastroparesis include gastrointestinal symptoms, especially nausea and vomiting, abdominal pain, and nutritional and metabolic changes that may arise as a result of abnormally delayed gastric emptying ${ }^{(4,14,21)}$.

Regarding etiology, gastroparesis is often associated with diabetes mellitus and post-surgical conditions, but, in substantial number of cases, etiology is not apparent and no underlying medical condition can be disclosed, thus comprising the so-called idiopathic gastroparesis ${ }^{(4,14)}$. In a previous review based on a large series of Brazilian patients, nearly $35 \%$ of the cases were of idiopathic gastroparesis ${ }^{(25)}$.

Nowadays, there is a variety of non-invasive methods for gastric emptying assessment, including non-invasive breath tests employing a variety of substrates, ultrasonography, magnetic resonance imaging and scintigraphy ${ }^{(10)}$. Among them, scintigraphy techniques, consisting of the acquisition of images of the abdomen after ingestion of test meals labeled with radioisotopes linked to unabsorbable carriers, are regarded as the most accurate ${ }^{(12)}$. It is of interest to note that scintigraphy allows studies to be carried out under near-physiological conditions, using natural meals, thus minimizing the undesirable influence of

Divisão de Gastroenterologia e Seção de Medicina Nuclear, Departamento de Clínica Médica, Faculdade de Medicina de Ribeirão Preto (FMRP), Universidade de São Paulo (USP), Brasil.

Correspondence: Prof. Luiz Ernesto de Almeida Troncon - Divisão de Gastroenterologia do Departamento de Clínica Médica - Hospital das Clínicas da Faculdade de Medicina de Ribeirão Preto - Campus Universidade de São Paulo. Av. Bandeirantes, 3900 - 14048-900, Ribeirão Preto, SP, Brasil. E-mail: ledatron@fmrp.usp.br 
variables related to the technique itself on the function to be assessed ${ }^{(10,12)}$.

Throughout the years, a considerable number of cases of gastroparesis were admitted in our center, which was mainly due to the possibility of offering access to a well standardized scintigraphy technique for assessing gastric emptying to the various clinics of a large general hospital; this made feasible that cases of suspected gastroparesis could be more objectively and accurately investigated. Nevertheless, a descriptive study of the demographic and clinical characteristics of these patients, and the relationships between these variables and the degree of gastric emptying delay is not available. Also, differences between subgroups of gastroparesis patients pertaining to different etiologies regarding demographic, clinical and gastric emptying data are not known.

This study aimed at describing the local series of Brazilian patients with gastroparesis, in relation to a previous one, which stimulated a review on the subject published elsewhere ${ }^{(25)}$, focusing on the demographic, clinical, and etiological characteristics, as well as the severity of the delay in gastric emptying. It was also intended to detail the characteristics of patients who, after extensive clinical investigation, no presumed etiology was found, which allowed diagnosing them as idiopathic gastroparesis. Furthermore, the study aimed at verifying whether the characteristics of the patients with gastroparesis associated with nervous system disease or diabetes mellitus, in whom autonomic neuropathy is likely to occur, differ from the other cases, especially those with idiopathic gastroparesis.

\section{METHODS}

This is a retrospective study carried out by analyzing medical records and gastric emptying tests of patients with suspected gastroparesis admitted in the wards and outpatient clinics of the Division of Gastroenterology, Department of Medicine, Ribeirão Preto Faculty of Medicine, University of São Paulo, University Hospital (HCRP) between 1998 and 2011. The local Ethics Research Committee previously approved the study (Statement HCRP Number 4169/2011) with waiver of signed informed consent forms, since current location and addresses of the patients included were not possible to be determined.

\section{Patients}

The study included 41 consecutive patients with gastroparesis, which presented with at least one symptom suggestive of delayed gastric emptying and had this abnormality confirmed by a specific scintigraphy assessment. On the day of the gastric emptying test, all patients had already been clinically investigated and no radiological and endoscopic evidence of mechanical obstruction of the gastroduodenal junction had been found.

\section{Clinical data}

The medical records of the patients included in the study were carefully reviewed in order to record demographic characteristics (age, gender) and clinical information. Data regarding the following variables were recorded: type and duration of gastrointestinal symptoms, presence or absence of weight loss, anthropometric data (weight, height, body mass index - BMI) and all clinical information pertaining to the diagnosis of diseases known to be associated with gastrointestinal motor disorders, including, in particular, diabetes mellitus and neurological conditions.

\section{Gastric emptying test}

In each case, the gastric emptying test previously performed by external abdominal scintigraphy after ingestion of either a liquid or a solid standard meal labelled with radioisotopes was reviewed. The test had been carried out according to techniques described elsewhere ${ }^{(2,26)}$ and standardized in the Section of Nuclear Medicine of the HCRP.

The solid meal consisting of a sandwich made with French bread $(50 \mathrm{~g})$, two scrambled eggs $(50 \mathrm{~g})$ and $15 \mathrm{~g}$ of margarine ( $420 \mathrm{kcal}, 25.1 \mathrm{~g}$ protein, and $20.2 \mathrm{~g}$ fat and $32.4 \mathrm{~g}$ carbohydrate) was prepared according to a previously published technique ${ }^{(2)}$. The liquid meal was also prepared in the laboratory ${ }^{(26)}$ and consisted of $64 \mathrm{~g}$ carbohydrate $20 \mathrm{~g}$ of proteins and $11 \mathrm{~g}$ of fat $(437 \mathrm{kcal}, 800 \mathrm{mOsm})$. Both meals were labelled with approximately $72 \mathrm{MBq}$ of ${ }^{99 \mathrm{~m}}$ Technetium molecules bound to phytate (IPEN, Instituto de Pesquisas Energéticas e Nucleares, São Paulo, Brazil), as a nonabsorbable carrier.

Test meals were ingested after a fasting period of at least 10 hours. Immediately after ingestion, images of the distribution of radioactivity over the abdomen were obtained with the patient standing between the two low-energy, high sensitivity parallel collimators of a gamma camera (Sopha Vision STD, Sopha Medical Vision America, Twinsburg, Ohio, USA). The acquisition system is connected to a computerized workstation for image and data processing (NXT Sopha Vision, Sopha Medical, USA). The gamma camera was programmed to acquire images with a $20 \%$ window around the $140 \mathrm{keV}$ photopeak of the ${ }^{99 \mathrm{~m}}$ Technetium.

Serial anterior and posterior images were acquired at every 5 minutes up to 30 minutes and then at every 10 minutes for 2 hours. Patients remained seated in the intervals between image acquisitions. All images were stored on magnetic tape or optical disk for further analysis.

The stored images of the anterior and posterior views of the abdomen after meal ingestion were outlined with a cursor to define regions of interest corresponding to the whole stomach. Counts obtained for the images acquired immediately after meal ingestion defined the initial activity. Counts obtained for the subsequent images were expressed as percentage of the initial activity, after automatic corrections for both the isotope decay and the antero-posterior movement of the marker in the body ${ }^{(24)}$. Analysis of gastric emptying data was performed as described elsewhere ${ }^{(26)}$. In particular, data of gastric retention at the various acquisition points yield the calculation of the gastric emptying half-time $\left(\mathrm{T}^{1 / 2}\right)$, the time taken for the initial activity to fall by half. Based on the individual results for the $\mathrm{T}_{1 / 2}$, patients were classified as having mild, moderate, severe 
or very severe gastric emptying delay, which was done based on the relationship between the value obtained and the upper limit of normality for the particular test meal (Table 1). The upper limits of normality for both liquid and solid meals corresponded, respectively, to 90 minutes and 120 minutes and derived from the distribution of individual values obtained from the results of dozens of asymptomatic volunteers included as control subjects in various investigation projects focusing on gastroduodenal motility in the two last decades.

TABLE 1. Criteria for definition of the severity of gastric emptying delay based on the relationships between observed values of $\mathrm{T}_{1 / 2}$ (the time taken by ingested radioactivity to fall by half) and the upper limits of normality (U.L.N.) for solid and liquid test meals. The limits between severity classes were set arbitrarily

\begin{tabular}{lccc}
\hline \multirow{2}{*}{$\begin{array}{l}\text { Severity } \\
\text { classes }\end{array}$} & $\begin{array}{c}\% \text { Above } \\
\text { U.L.N.* }\end{array}$ & \multicolumn{2}{c}{ U. L. N. (min) } \\
\hline Mild & Up to $10 \%$ & Liquid meal & Solid meal \\
Moderate & Up to $20 \%$ & $100-108$ & $121-132$ \\
Severe & Up to 30\% & $109-117$ & $143-144$ \\
Very severe & $>30 \%$ & $>117$ & $>156$ \\
\hline
\end{tabular}

* Values for the U.L.N. for liquid and solid test meals corresponded, respectively, to $90 \mathrm{~min}$ and $120 \mathrm{~min}$ and derived from dozens of asymptomatic subjects included as controls in research protocols during the last 20 years

\section{Statistical analysis}

Comparisons between different subgroups of patients with gastroparesis were performed using the Fisher's exact probability test and regarded as statistically significant the differences associated with $p$ values of less than 0.05 . These comparisons included the proportions of patients in relation to the following variables: gender (females), age (less than 25 years at the symptoms onset), symptom duration (less than 2 years), symptom type and degree of delayed gastric emptying (severe or very severe).

\section{RESULTS}

\section{Patient demographic data}

Among the 41 patients, $31(75.6 \%)$ were women. Age ranged between 18 and 67 years (median: 41 years). The BMI of the patients in this series ranged from 15.2 to 28.4 $\mathrm{kg} / \mathrm{m}^{2}$ (median: $22 \mathrm{~kg} / \mathrm{m}^{2}$ ), and $12(29.2 \%)$ of them had values lower than $20 \mathrm{~kg} / \mathrm{m}^{2}$.

\section{Etiology}

Based on the most likely etiology of gastroparesis, patients were divided into five subgroups (Table 2): 1) digestive diseases, comprising $16(39.0 \%)$ patients and including idiopathic gastroparesis, which was the final diagnosis in $12(29.3 \%)$ patients; 2$)$ post-surgical conditions, consisting of $12(29.3 \%)$ patients; 3$)$ diseases of the nervous system, consisting of $5(12.2 \%)$ patients; 4$)$ diabetes mellitus comprising $5(12.2 \%)$ patients; 5) miscellaneous, including $3(7.3 \%)$ patients. The clinical conditions underlying gastroparesis in the patients of each etiologic group are presented in table 2 .
TABLE 2. Number of cases (and percentages) and associated clinical conditions of each of five different etiological groups in which each of the 41 patients with gastroparesis admitted in a single Brazilian center between 1998 and 2011 were allocated

\begin{tabular}{|c|c|c|}
\hline $\begin{array}{l}\text { Etiological } \\
\text { group }\end{array}$ & $\begin{array}{l}\text { Number } \\
\text { of cases } \\
(\%)\end{array}$ & Associated clinical conditions \\
\hline $\begin{array}{l}\text { 1. Digestive } \\
\text { diseases }\end{array}$ & $\begin{array}{c}16 \\
(39.0)\end{array}$ & $\begin{array}{l}\text { Idiopathic gastroparesis }(\mathrm{n}=12) \\
\text { Gastro-esophageal reflux disease }(\mathrm{n} \\
=3) \\
\text { Pseudo-obstruction -generalized } \\
\text { motor disorder }(\mathrm{n}=1)\end{array}$ \\
\hline 2. Post-surgical & $\begin{array}{c}12 \\
(29.3)\end{array}$ & $\begin{array}{l}\text { Fundoplication }(n=4) \\
\text { Biliary-digestive diversion }(n=4) \\
\text { Antrectomy plus vagotomy }(n=3) \\
\text { Partial gastrectomy - bariatric surgery } \\
(n=1)\end{array}$ \\
\hline $\begin{array}{l}\text { 3. Nervous } \\
\text { system diseases }\end{array}$ & $\begin{array}{c}5 \\
(12.2)\end{array}$ & $\begin{array}{l}\text { Multiple sclerosis }(\mathrm{n}=2) \\
\text { Mitochondrial neuropathy }(\mathrm{n}=2) \\
\text { Demyelinating polineuropathy }(\mathrm{n}=1)\end{array}$ \\
\hline $\begin{array}{l}\text { 4. Diabetes } \\
\text { mellitus }\end{array}$ & $\begin{array}{c}5 \\
(12.2)\end{array}$ & $\begin{array}{l}\text { Type I }(\mathrm{n}=3) \\
\text { Type II }(\mathrm{n}=2)\end{array}$ \\
\hline 5. Miscellaneous & $\begin{array}{c}3 \\
(7.3)\end{array}$ & $\begin{array}{l}\text { Total abdominal situs inversus }(\mathrm{n}=1) \\
\text { Chagas' disease }(\mathrm{n}=1) \\
\text { Anorexia nervosa }(\mathrm{n}=1)\end{array}$ \\
\hline
\end{tabular}

\section{Presented symptoms}

Dyspepsia (epigastric discomfort, fullness, bloating, early satiety, frequent belching) was present in $22(53.6 \%)$ patients, nausea and vomiting in $19(46.3 \%)$, weight loss in $17(41.4 \%)$, abdominal pain in $10(24.3 \%)$ and changes in bowel habits, characterized by diarrhea or constipation, in seven $(17.0 \%$ ) patients (Table 3). However, seven patients who did not complain of weight loss had BMI values lower than $20 \mathrm{~kg} / \mathrm{m}^{2}$, which allowed estimating the presence of emaciation in $58.5 \%(24 / 41)$ of the cases. There was no association between symptoms and etiology of gastroparesis $(P>0.20)$.

TABLE 3. Number of cases (and percentages) with different symptoms among 41 patients with gastroparesis admitted in a single Brazilian center between 1998 and 2011.

\begin{tabular}{lc}
\hline Symptoms & Number of patients $(\%)$ \\
\hline Dyspepsia & $22(53,6)$ \\
Nausea and vomiting & $19(46,3)$ \\
Weight loss* & $17(41.4)$ \\
Abdominal pain & $10(24,3)$ \\
Diarrhea or constipation & $7(17,0)$ \\
\hline
\end{tabular}

*Seven other patients who did not complained of weight loss had values of Body Mass Index lower than $20 \mathrm{Kg} / \mathrm{m}^{2}$, which allowed estimates this clinical manifestation as occurring in 24 $(58.5 \%)$ cases.

The duration of symptoms experienced by patients with gastroparesis ranged from 1.5 months to 360 months (30 years), with a median of 180.75 months (15.1 years).

\section{Severity of gastric emptying delay}

Among the 41 patients, $27(65.8 \%)$ had delayed gastric emptying classified as severe or very severe; these categories 
predominated in all etiological groups, except for that consisting of three patients with different etiologies (miscellaneous), in which two patients had mild or moderate delay (Table 4).

TABLE 4. Relationships between etiology and severity of gastric emptying delay in 41 patients with gastroparesis admitted in a single Brazilian center between 1998 and 2011. Data correspond to number of cases (and percentages)

\begin{tabular}{|c|c|c|c|}
\hline \multirow{2}{*}{$\begin{array}{l}\text { Etiological } \\
\text { group }\end{array}$} & \multicolumn{2}{|c|}{ Delay severity } & \multirow[b]{2}{*}{ Total } \\
\hline & $\begin{array}{c}\text { Mild moderate } \\
(\%)\end{array}$ & $\begin{array}{c}\text { Severe/very severe } \\
(\%)\end{array}$ & \\
\hline $\begin{array}{l}\text { Digestive diseases } \\
\text { (including idiopathic } \\
\text { gastroparesis) }\end{array}$ & $7(43,7)$ & $9(56,2)$ & 16 \\
\hline Post-surgical & $4(33,3)$ & $8(66,7)$ & 12 \\
\hline $\begin{array}{l}\text { Nervous system } \\
\text { diseases }\end{array}$ & $1(20,0)$ & $4(80,0)$ & 5 \\
\hline Diabetes mellitus & - & $5(100)$ & 5 \\
\hline Miscellaneous & $2(66,7)$ & $1(33,3)$ & 3 \\
\hline Total & $14(34,2)$ & $27(65,8)$ & 41 \\
\hline
\end{tabular}

There was no association between etiology of gastroparesis and the degree of delayed gastric emptying $(P>0.50)$. There was also no association $(P>0.20)$ between symptom type and the severity of delayed gastric emptying, since severe or very severe delay predominated in all symptom-based subgroups (Table 5).

TABLE 5. Relationships between etiology and severity of gastric emptying delay in 41 patients with gastroparesis admitted in a single Brazilian center between 1998 and 2011. Data correspond to number of cases (and percentages).

\begin{tabular}{|c|c|c|c|}
\hline \multirow[b]{2}{*}{ Symptoms } & \multicolumn{2}{|c|}{ Delay severity } & \multirow[b]{2}{*}{ Tota } \\
\hline & $\begin{array}{l}\text { Mild moderate } \\
(\%)\end{array}$ & $\begin{array}{c}\text { Severe/very severe } \\
(\%)\end{array}$ & \\
\hline Dyspepsia & $7(31,8)$ & $15(68,2)$ & 22 \\
\hline $\begin{array}{l}\text { Nausea and } \\
\text { vomiting }\end{array}$ & $4(21,0)$ & $15(79,0)$ & 19 \\
\hline Weight loss & $3(17,6)$ & $14(82,4)$ & 17 \\
\hline Abdominal pain & $4(40,0)$ & $6(60,0)$ & 10 \\
\hline $\begin{array}{l}\text { Diarrhea or } \\
\text { constipation }\end{array}$ & $2(28,6)$ & $5(71,4)$ & 7 \\
\hline
\end{tabular}

\section{Characteristics of patients with idiopathic gastroparesis}

In this subgroup consisting of 12 patients there was only one man; age ranged between 18 and 65 years (median: 35.5 years). Eight (66.6\%) patients had dyspepsia, four (33.3\%) had nausea and vomiting and only two $(16.6 \%)$ cases presented with abdominal pain. Loss of body weight or BMI reduction was present in three $(25 \%)$ patients. Symptom duration ranged from one to 30 years (median: 5 years). The delay in gastric emptying was classified as severe or very severe in seven $(58.3 \%)$ cases.

\section{Characteristics of patients with gastroparesis associated to diseases of the nervous system or diabetes mellitus}

In this subgroup comprising 10 patients with proven or presumed (diabetes mellitus) neurological conditions there were $7(70.0 \%)$ women. Age ranged from 22 years to 68 years (median: 45 years), and $4(40 \%)$ patients were aged less than or equal to 25 years.

Regarding presented symptoms, five (50\%) complained of weight loss or had BMI values lower less than $20 \mathrm{~kg} / \mathrm{m}^{2}$, four had dyspepsia, four had nausea and vomiting and only one had abdominal pain. Five $(50 \%)$ patients in this group had constipation or diarrhea. The duration of symptoms ranged from 1.5 months to 30 months (median: 15 months), and symptom duration was shorter than 2 years in seven patients. Gastric emptying delay was classified as very severe in nine $(90 \%)$ out of the 10 patients in this subgroup.

Comparing this subgroup with the remaining patients with gastroparesis associated to other etiologies, including the idiopathic cases, there were significantly higher proportions of younger patients $(P=0.001)$ and more recent symptom onset $(P=0.03)$. Severe or very severe gastric emptying delay tended to be more frequent in this subgroup than in patients of other etiologies, but statistical significance was not reached $(P=0.06)$. There were no significant differences between this subgroup and the remaining patients regarding the proportion of women and the frequency of any type of symptom presented.

There were no statistically significant differences between this subgroup of patients with proven or presumed (diabetes mellitus) neurological conditions and that with idiopathic gastroparesis, in relation to any of the variables studied.

\section{DISCUSSION}

In this paper, we described 41 cases of gastroparesis admitted in a single tertiary referral center along nearly 15 years. Although these data may suggest that gastroparesis is a common clinical condition, knowledge about how frequently gastroparesis cases are seen in clinical practice is limited, since studies on its prevalence and incidence are scarce. A few epidemiological studies from North America showed prevalence figures of 9.6 cases per 100,000 men and 37.8 cases per 100,000 women $^{(9)}$, and an estimated frequency of $1.8 \%$ of the general population ${ }^{(20)}$. However, these studies may have overestimated the actual frequency, by considering gastroparesis in a broader sense and including cases of functional dyspepsia, who may also have delayed gastric emptying ${ }^{(22,23,26)}$. Functional dyspepsia is a highly common condition defined by symptoms suggestive of gastroduodenal disease without evidence of organic impairment ${ }^{(23)}$. In fact, the conceptual overlap between functional dyspepsia and gastroparesis have been better recognized in recent years, but the distinction between them can be problematic in many cases ${ }^{(15)}$. On the other hand, gastroparesis may also be diagnosed even in asymptomatic cases, by recognizing 
manifestations of its complications, such as severe forms of reflux esophagitis, the erratic absorption of drugs and the difficulty of metabolic control in diabetic patients ${ }^{(25,27)}$, which make estimation of incidence and prevalence more difficult.

Our series of 41 patients seen over a period of nearly 15 years is perhaps the largest in the country and is comparable to one of the largest series of patients with gastroparesis described elsewhere, which included 243 cases from seven different U.S. centers, on a 5 -year period ${ }^{(16)}$. It must be considered however that ours is a reference center for gastrointestinal motility disorders, which may indicate that the frequency possible to be inferred from this report is probably much higher than the expected occurrence of this condition in the general population.

There was a definite predominance of females $(75.6 \%)$ among the cases herein presented, which is in line with other studies that found more than $80 \%$ women in all etiologic groups of gastroparesis ${ }^{(7,16,21)}$. The reasons for this predominance of females are unknown, but it is plausible that they may relate to hormonal factors. Gastric emptying in women in the premenstrual phase is physiologically delayed ${ }^{(11)}$ and the severity of the delay in stomach emptying seems to be lower in gastroparetic women in menopause, when compared to other patients ${ }^{(16)}$. Since the present report derived from a retrospective study, it was not possible to stratify women as being or not in menopause, nor verify whether they were in the first or in the second stage of the menstrual cycle when attend the gastric emptying test. This limits the contribution this paper might bring to the knowledge on the relationships between female gender and gastroparesis.

The distribution of the 41 patients in the various etiologic groups does not differ substantially from that described in other studies, which highlight the important participation of cases of unknown cause (idiopathic gastroparesis), those associated with diabetes mellitus and those arising from previous operations affecting the stomach ${ }^{(4,27)}$. Occasional differences in the relative proportions of each of these groups are likely to be due to either referral bias or differences regarding prevalence of the underlying conditions in the populations from which the cases came from. This kind of influence can be exemplified by comparing the current and previous series ${ }^{(25)}$ from the same center. In the former series, post-surgical cases accounted for less than $20 \%$ of the total and consisted mainly of patients who had underwent antrectomy for peptic ulcer diseases, whereas post-surgical gastroparesis in the patients herein presented corresponded to $29.3 \%$ and comprised many more patients submitted to fundoplication for the treatment of gastroesophageal reflux disease than those who had antrectomy (Table 2). Similarly, the previous sample contained many more cases of patients with diabetes mellitus, which might be ascribed to a higher degree of awareness for diabetic gastroparesis in the past. It is likely that this is taking place nowadays with neurologists, thus explaining the relatively higher proportion of cases of gastroparesis associated with diseases of the central nervous system in the current series (Table 2).

Both type and distribution of symptoms in the patients herein reported current series are similar to those described by others ${ }^{(16,21)}$, except for weight loss or reduced BMI, which we found in more than half of our cases. This is in contrast to the study of Parkman and co-workers ${ }^{(16)}$, who reported that the majority of their patients had normal weight or body mass, were overweighted or even had obesity. This difference, again, could be due to conceptual diversity regarding what is gastroparesis influencing the inclusion criteria. It is plausible that among their patients there were cases of functional dyspepsia with delayed gastric emptying, which, in our view, comprise an entity distinct from gastroparesis.

We have not found any significant association between predominant symptoms, etiology of gastroparesis and the severity of delayed gastric emptying, which somehow disagrees to other's reports ${ }^{(18,19)}$. This could be explained by one limitation of the present work: because ours is a retrospective study, symptoms were described in terms of type only, based on data from history taking. This contrasts to other's prospective studies that utilized standardized and validated instruments covering both type, frequency and intensity of presented symptoms, such as the "Patient Assessment of Upper GI Symptoms" (PAGI-SYM) ${ }^{(18)}$ and the "Gastroparesis Cardinal Symptom Index" (GCSI) ${ }^{(19)}$.

Another limitation of this retrospective study was the use of a locally standardized test method for gastric emptying assessment, which hinders comparison of our results with those from other centers. Both the "American Neurogastroenterology and Motility Society" and the "Society of Nuclear Medicine" jointly recommends a technique whose main components are the use of a solid meal similar to that employed by us, but with a test duration of at least four hours ${ }^{(1)}$. In many of our cases, gastric emptying was assessed with a liquid meal. This occurred because at our center this type of meal is used in a study protocol which allows not only the measurement of stomach emptying, but also the study of other aspects of gastric motility, such as antral contractility and gastric fundal accommodation of the ingested test meal ${ }^{(26)}$.

While less accurate than a solid meal for detecting abnormally delayed gastric emptying, the liquid test meal was chosen in many instances based on the suspicion of acceleration of the early phase of the stomach evacuation. This phenomenon, which occurs in patients with impaired gastric receptive relaxation usually associated with denervation of the stomach and may coexist with delayed emptying ${ }^{(17)}$, can be better characterized with the use on scintigraphy of a liquid meal. Nevertheless, the establishment of a common criteria for classifying the severity of delayed gastric emptying encompassing the two types of meal (Table 1) might be considered as a factor that minimizes the limitation of not having used the solid meal in all cases.

Regardless of the method used for assessing stomach evacuation, it is important to characterize the degree of gastric emptying retardation, since there is evidence that the delay severity can be predictive of response to treatment, especially in patients with idiopathic gastroparesis, in which the subgroup of patients with less severe delay seems 
to show a better response to prokinetics ${ }^{(8)}$. In this respect, the majority of the cases herein presented had a remarkable delay in gastric emptying, which is similar to that described by others ${ }^{(3,8,16)}$. However, as in these studies, our cases came from a tertiary referral center, which limits the scope of the results concerning the delineation of the whole spectrum of possible emptying abnormalities existing in gastroparesis.

In this study, we do not found no significant differences between the subgroups of patients with idiopathic gastroparesis and that comprising the cases with proven (Nervous System diseases) or presumed (diabetes mellitus) neurologic disorders. This finding is similar to that from a recent study ${ }^{(3)}$, but differs from another ${ }^{(16)}$ which showed that diabetic patients, when compared to those with idiopathic gastroparesis, were older, had less weight loss body and had more vomiting and were less affected by abdominal pain, as well as had more severe gastric emptying delay. However, the differences between the present study and that above mentioned ${ }^{(16)}$ regarding the number of cases and the methods employed makes it difficult to compare the findings.

In the subgroup comprised by patients with proven (nervous system disease) or presumed (diabetes mellitus) neural dysfunction, cases of younger patients, with more recent symptom onset and a trend towards slower gastric emptying were more frequent. This suggests that, in cases of gastroparesis presenting with a combination of these characteristics, the occurrence of a putative neurological disease leading to impaired e neural control of gastric motility should be suspected and therefore investigated. In practical terms, this finding suggests that in cases of gastroparesis not preliminarily associated with any known underlying conditions, it is imperative to rule out both diabetes mellitus and neurological disease, before diagnosing idiopathic gastroparesis.

Similarly, lack of significant differences between this subgroup of patients and that comprised by cases with idiopathic gastroparesis may suggest that in this latter condition the pathophysiological abnormality underlying delayed gastric emptying relates to impaired neural control of gastro-duodenal motility, even though the occurrence of a neurological disease is not apparent. In fact, recent studies on tissue changes in gastric wall in patients with gastroparesis ${ }^{(5,}$ ${ }^{6}$ ) have found that in both diabetic and idiopathic cases there is substantial damage to the myoenteric plexus and to the interstitial cells of Cajal, which are essential components involved in the neural control of gastric motility.

Finally, the results of this retrospective study relates to epidemiological, etiological and pathophysiological aspects of gastroparesis, which may eventually inform diagnosis. Nevertheless, it is unclear whether knowledge about clinical characteristics at admission and the severity of gastric emptying delay in gastroparesis could predict patient responses to lifestyle and diet-related measures, or pharmacological treatment. The clarification of this important issue requires further studies.

\section{CONCLUSIONS}

This retrospective study of medical records and gastric emptying tests from 41 consecutive Brazilian patients with gastroparesis showed that the demographic, clinical and etiological characteristics are quite variable, but there is a predominance of women with long-term symptoms and marked delay in gastric emptying. The type of presented symptoms and the severity of gastric emptying delay do not predict the etiology of gastroparesis. However, severely delayed gastric emptying in younger patients with recent onset symptoms should raise the suspicion of impaired neural control of gastric motility. Patients with idiopathic gastroparesis have clinical characteristics and degree of delayed gastric emptying similar to cases with proven (diseases of the nervous system) or presumed (diabetes mellitus) neurological dysfunction.

\section{AKNOWLEDGEMENTS}

This work was supported by grants from the Brazilian agencies CNPq and FAPESP. Cláudio Marins Rocha Borges was the recipient of a student fellowship grant from the program USP/PIBIC.

Borges CMR, Secaf M, Troncon LEA. Características clínicas e grau de retarde do esvaziamento gástrico em pacientes brasileiros com gastroparesia. Arq Gastroenterol. 2013,50(4):270-6.

RESUMO - Contexto - A gastroparesia é uma condição clínica definida por retarde anormal do esvaziamento gástrico, sem obstrução mecânica antro-piloro-duodenal, que vem sendo crescentemente estudada. No entanto, as relações entre etiologia, sintomas e grau de retarde do esvaziamento gástrico na gastroparesia são ainda pouco conhecidas. Objetivos - Estudar as características demográficas, clínicas e etiológicas e o grau de retarde do esvaziamento gástrico em pacientes brasileiros com gastroparesia e comparar os casos idiopáticos com aqueles com doenças do sistema nervoso ou diabete melito, em que é alta a probabilidade de ocorrência de neuropatia autonômica. Método - Estudo retrospectivo dos prontuários de 41 casos com sintomas sugestivos de gastroparesia admitidos entre 1998 e 2011, que tiveram comprovação de retarde anormal do esvaziamento gástrico em exame cintigráfico específico, que foi também revisto. Resultados - Dentre os 41 casos, 31 (75,6\%) eram mulheres; a mediana de idade foi de 41 anos e predominou quadro clínico de longa duração (mediana: 15 anos). Doze $(29,26 \%)$ pacientes apresentavam índice de massa corporal inferior ao limite de $20 \mathrm{~kg} / \mathrm{m}^{2}$. Os sintomas mais frequentes foram a dispepsia (53,6\%), náuseas e vômitos (46,3\%), perda de peso (41,4\%) e dor abdominal (24,3\%). Quanto à etiologia, 16 pacientes tinham afecções digestivas, incluindo a gastroparesia idiopática $(\mathrm{n}=12), 12$ eram de estados pós-operatórios, 11 tinham doenças do sistema nervoso, 5 tinham diabete melito e 3 eram de etiologias variadas. A maioria dos pacientes (65,8\%) apresentou retarde do esvaziamento gástrico intenso ou muito intenso. Não houve qualquer associação entre etiologia da gastroparesia, sintomas apresentados e grau de retarde do esvaziamento gástrico. Nos casos com comprometimento neurológico comprovado ou presumido (diabéticos), os pacientes eram signif- 
icativamente mais jovens $(P=0.001)$, com início mais recente dos sintomas $(P=0.03)$ e com tendência a retarde mais acentuado do esvaziamento gástrico $(P=0.06)$. Não houve diferença significativa entre este subgrupo e os casos de gastroparesia idiopática quanto a nenhuma das variáveis estudadas. Conclusões - As características clínicas e demográficas dos casos de gastroparesia são variadas, mas há predomínio de mulheres com quadro clínico de longa duração. Os sintomas apresentados e o grau de retarde do esvaziamento gástrico não predizem a etiologia da gastroparesia. No entanto, retarde muito intenso do esvaziamento gástrico em pacientes mais jovens e com sintomas de início mais recente devem levantar a suspeita de prejuízo ao controle neural da motilidade gástrica. Pacientes com gastroparesia idiopática tem características clínicas e grau de retarde do esvaziamento gástrico semelhantes aos de casos com comprometimento neurológico comprovado ou presumido.

DESCRITORES - Gastroparesia. Sinais e sintomas digestórios. Neuropatias. Diabetes mellitus.

\section{REFERENCES}

1. Abell TL, Camilleri M, Donohoe K, Hasler WL, Lin HC, Maurer AH, McCallum RW, Nowak T, Nusynowitz ML, Parkman HP, Shreve P, Szarka LA, Snape Jr WJ, Ziessman HA. Consensus recommendations for gastric emptying scintigraphy: a joint report of the American Neurogastroenterology and Motility Society and the Society of Nuclear Medicine. Am J Gastroenterol. 2008;103:753-63.

2. Aprile LRO, Meneghelli UG, Martinelli ALC, Monteiro CR. Gastric motility in patients with presinusoidal portal hypertension related to the reduced gastric wall compliance. Am J Gastroenterol. 2002;97:3038-44.

3. Camilleri M, Grover M, Farrugia G. What are the important subsets of gastroparesis? Neurogastroenterol Motil. 2012;24:597-603.

4. Camilleri M, Parkman HP, Shafi MA, Abell TL, Gerson L. Clinical Guideline: management of gastroparesis. Am J Gastroenterol. 2013;108:18-37.

5. Grover M, Farrugia G, Lurken MS Bernard CE, Faussone-Pellegrini MS, Smyrk TC, Parkman HP, Abell TL, Snape WJ, Hasler WL, Ünalp-Arida A, Nguyen L, Koch KL, Calles J, Lee L, Tonascia J, Hamilton FA, Pasricha PJ; NIDDK Gastroparesis Clinical Research Consortium. Cellular changes in diabetic and idiopathic gastroparesis. Gastroenterology. 2011;140:1575-85.

6. Grover M, Bernard CE, Pasricha PJ, Lurken MS, Faussone-Pellegrini MS, SMYRK TC, Parkman HP, Abell TL, Snape WJ, Hasler WL, McCallum RW, Nguyen L, Koch KL, Calles J, Lee L, Tonascia J, Nalp-Arida AU, Hamilton FA, Farrugia G; NIDDK Gastroparesis Clinical Research Consortium (GPCRC). Clinical-histological associations in gastroparesis: results from the Gastroparesis Clinical Research Consortium. Neurogastroenterol Motil. 2012;24:531-e249.

7. Harrell SP, Studts JL, Dryden GW, Eversmann J, Cai L, Wo JM. A novel classification scheme for gastroparesis based on predominant-symptoms presentation. J Clin Gastroenterol. 2008;42:455-59.

8. Hejazi RA, Sarosiek I, Roeser K, McCallum RW. Does grading the severity of gastroparesis based on scintigraphic gastric emptying predict the treatment outcome of patients with gastroparesis? Dig Dis Sci. 2011;56:1147-53.

9. Jung HK, Choung RS, Locke GR, Schleck CD, Zinsmeister AR, Szarka LA, Mullan B, Talley NJ. The incidence, prevalence, and outcomes of patients with gastroparesis in Olmsted County, Minnesota, from 1996 to 2006. Gastroenterology. 2009;136:1225-33.

10. Kim DY, Myung SJ, Camilleri M. Novel testing of human gastric motor and sensory functions: rationale, methods, and potential applications in clinical practice. Am J Gastroenterol. 2000;95:3365-73.

11. Knight LC, Parkman HP, Brown KL, Miller MA, Trate DM, Maurer AH, Fisher RS. Delayed gastric emptying and decreased antral contractility in normal premenopausal women compared with men. Am J Gastroenterol. 1997;92:968-75.

12. Maurer AH. Advancing Gastric Emptying Studies: Standardization and New Parameters to Assess Gastric Motility and Function. Semin Nucl Med. 2012;42:101-12.

13. Park MI, Camilleri M. Gastroparesis: clinical update. Am J Gastroenterol. 2006;101:1129-39.
14. Parkman HP, Hasler WL, Fisher RS. American Gastroenterological Association technical review on the diagnosis and treatment of gastroparesis. Gastroenterology. 2004;127:1592-622.

15. Parkman HP, Camilleri M, Farrugia G, McCallum RW, Bharucha AE, MayeR EA, Tack J, Spiller R, Horowitz M, Vinik AI, Galligan JJ, Pasricha PJ, Kuo B, Szarka LA, Marciani L, Jones K, Parrish CR, Sandroni P, Abell T, Ordog T, Hasler W, Koch KL, Sanders K, Norton NJ, Hamilton F. Gastroparesis and functional dyspepsia: excerpts from the AGA/ANMS meeting. Neurogastroenterol Motil. 2010;22:113-33.

16. Parkman HP, Yates K, Hasler WL, Nguyen L, Pasricha PJ, Snape WJ, Farrugia G, Koch KL, AbelL TA, McCallum RW, Lee L, Unalp-Arida A, Tonascia J, Hamilton F, on behalf of the National Institute of Diabetes and Digestive and Kidney Diseases Gastroparesis Clinical Research Consortium. Clinical Features of Idiopathic Gastroparesis Vary With Sex, Body Mass, Symptom Onset, Delay in Gastric Emptying, and Gastroparesis. Gastroenterology. 2011;140:101-115.

17. Quigley EMM. Gastric motor and sensory function and motor disorders of the stomach. In: Sleisenger \& Fordtrand's Gastrointestinal and Liver Disease. Mark Feldman, Lawrence S. Friedman, Lawrence Brandt (editores), 8a. ed., Saunders - Elsevier, Philadelphia, USA. p. 999 - 1028.

18. Rentz AM, Kahrilas P, Stanghellini V, Tack J, Talley NJ, de la Loge C, Trudeau E, Dubois D, Revicki DA. Development and psychometric evaluation of the patient assessment of upper gastrointestinal symptom severity index (PAGI-SYM) in patients with upper gastrointestinal disorders. Qual Life Res. 2004;13:1737-49.

19. Revicki DA, Rentz AM, Dubois D, Kahrilas P, Stanghellini V, Talley NJ, Tack J. Development and validation of a patient-assessed gastroparesis symptom severity measure:the Gastroparesis Cardinal Symptom Index. Aliment Pharmacol Ther. $2003 ; 18: 141-50$

20. Rey E, Choung RS, SchlecK CD, Zinsmeister AR, Talley NJ, Locke GR. Prevalence of hidden gastroparesis in the community: the gastroparesis 'iceberg'. J Neurogastroenterol Motil. 2012;18:34 42 .

21. Soykan I, Sivri B, Sarosiek I, Kiernan B, McCallum RW. Demography, clinical characteristics, psychological and abuse profiles, treatment, and longterm follow-up of patients with gastroparesis. Dig Dis Sci. 1998;43:2398-404.

22. Tack J, Talley NJ, Camilleri M, Holtmann G, Hu P, Malagelada JR, Stanghellin V. Functional gastroduodenal disorders. Gastroenterology. 2006;130:1466-79.

23. Talley NJ, Stanghellini V, Heading RC, Koch KL, Malagelada JR, Tytgat GNJ Functional gastroduodenal disorders. Gut 1999;45 (Suppl. II):37-42.

24. Tothill P, MaClouhglin GP, Heading RC. Techniques and errors in scintigraphic measurements of gastric emptying. J Nucl Med. 1978;19:256-61.

25. Troncon LEA. Gastroparesias: revisão de aspectos ligados ao conceito, à etiopatogenia e ao manejo clínico. Rev Assoc Med Bras 1997;43:228-36.

26. Troncon LEA, Herculano-Jr JR, Savoldelli RD, Moraes ER, Secaf M, Oliveira RB. Relationships between intragastric food maldistribution, disturbances of antral contractility and symptoms in functional dyspepsia. Dig Dis Sci. 2006;51:517-26.

27. Waseem S, Moshiree B, Draganov PV. Gastroparesis: current diagnostic challenges and management considerations. World J Gastroenterol. 2009;15:25-37. 